\title{
Immunomodulatory properties of enzymatic extract of Stichopus japonicus on murine splenocytes
}

\author{
Suyama Prasansali Mihindukulasooriya', Bohyung Kim², Duong Thi Thuy Dinh", \\ Kalahe Hewage Iresha Nadeeka Madushani Herath ${ }^{1}$, Jinhee $\mathrm{Cho}^{2}$, Hyo Jin Kim ${ }^{3}$, Jiwon Yang ${ }^{4}$, \\ Youngheun Jee $\mathrm{J}^{1,2, *}$ \\ ${ }^{1}$ Interdisciplinary Graduate Program in Advanced Convergence Technology \& Science, Jeju National University, Jeju 63243, Korea \\ ${ }^{2}$ Department of Veterinary Medicine and Veterinary Medical Research Institute, Jeju National University, Jeju 63243, Korea \\ ${ }^{3}$ Department of Food Bioengineering, Jeju National University, Jeju 63243, Korea \\ ${ }^{4}$ Department of Animal Biotechnology, Faculty of Biotechnology, Jeju National University, Jeju 63243, Korea
}

\begin{abstract}
Red sea cucumber Stichopus japonicus is an invertebrate animal inhabiting in coasts of Korea, China, and Japan. They are traditionally used for food and medicine and well known for their distinctive biologically and pharmacologically important compounds. We investigated the effect of amyloglucosidase (AMG) enzymatic extracts of S. japonicus (AESJ) on the proliferation and cytokine secretion of murine splenocytes stimulated with concanavalin A (Con A). AESJ enhanced the proliferation of splenocytes and the production of IL-2 (Th1 cytokine), IL-1 13 (Th1 promoting cytokine), and IL-4, IL-10 (Th2 type cytokines) when treated alone. However, under Con A stimulation, AESJ suppressed the proliferation of splenocytes, attenuated the secretion of IL-2, IL-4, IL-10, and enhanced IL-1 $\beta$ secretion. These results suggest that AESJ exhibits immunomodulatory effect by moderating the proliferation of splenocytes and the secretion of IL-2, IL-1 $\beta, \mathrm{IL}-4$, and IL-10 differently depending on the absence and presence of Con A stimulation. These data evidence the immunomodulatory potential of AESJ, which can be further developed into a functional food mediating homeostasis.
\end{abstract}

Keywords: Stichopus japonicus, Sea cucumber, Enzymatic extracts, Splenocytes, Immunomodulation

\section{Introduction}

The immune system is a functional system consists of cells and molecules that are able to stand against foreign substances and responsible for the protection of hosts. Immunomodulation either by immune stimulators or suppressors is of great interest for a variety of conditions. They modulate the immune response and keep the host defended against pathogens or tumors. Furthermore, they potentiate the host and keep it prepared for future pathologic threats (Abood et al., 2014; Azam et al., 2019). Recently, considerable attention has been focused on natural products with immune modulatory effect as an alternative to

Received: Jun 10, 2021 Revised: Jul 31, 2021 Accepted: Aug 8, 2021

${ }^{*}$ Corresponding author: Youngheun Jee

Department of Veterinary Medicine and Veterinary Medical Research Institute, Jeju National University, Jeju 63243, Korea

Tel: +82-64-754-3374, Fax: +82-64-756-3354, E-mail: yhjee@jejunu.ac.kr

This is an Open Access article distributed under the terms of the Creative Commons Attribution Non-Commercial License (http://creativecommons.org/licenses/by$\mathrm{nc} / 4.0 /$ ) which permits unrestricted non-commercial use, distribution, and reproduction in any medium, provided the original work is properly cited.

Copyright $\odot 2021$ The Korean Society of Fisheries and Aquatic Science 
artificial synthetic drugs to avoid resistance or other side effects for treating immune disorders (Ortuño-Sahagún et al., 2017).

Red sea cucumber Stichopus japonicus, a marine invertebrate inhabiting the benthic and deep sea areas, is famous as a food or a medicine around Korea, Russia, China, and Japan (Oh et al., 2017; Taiyeb-Ali et al., 2003). S. japonicus's body wall, the main edible part, mainly consists of mucopolysaccharides and collagen (Duan et al., 2010). Moreover, it is rich with natural peptides, sphingosine, saponins, vitamins, 18 amino acids and nutritional supplements (Bordbar et al., 2011). The active components such as collagen, saponin and polysaccharides are reported to be responsible for the exhibited anti-oxidant, anti-cancer, anti-coagulant activities (Khotimchenko, 2018; Wargasetia \& Widodo, 2017). Ethyl acetate fraction of S. japonicus was reported to inhibit lipopolysaccharide induced inflammatory responses in murine macrophages by suppressing the MAPK pathway, which in turn reduced inducible nitric oxides and cyclooxygenase- 2 protein expression, and attenuated the secretion of IL-1 $\beta$ and TNF- $\alpha$ (Himaya et al., 2010). It is interesting to note that polypeptides in S. japonicus exhibited anti-fatigue and immune functions in rats with no obvious effect on body weight (Ye et al., 2017).

Natural products' efficacy varies heavily depending on its extraction method. To select an appropriate extraction method puts stark limits on its active components and their biological properties (Wijesinghe \& Jeon, 2012). For instance, water and organic extraction methods have low yields compared with enzymatic extraction methods (Heo et al., 2005). Although bioactive polysaccharides are massively contained in the marine organisms, it is inefficient to extract them using conventional chemical and mechanical extraction methods (Wijesinghe \& Jeon, 2012). Moreover, efficient enzymatic extraction methods also increase food safety compared with other methods utilizing organic solvents (Azam et al., 2019; Wijesinghe \& Jeon, 2012). Previously, amyloglucosidase extracts indeed revealed higher polysaccharide contents than other digests (Affan et al., 2009). But, the understanding of immunological function of amyloglucosidase extracts still remains to be elusive.

In the present study, we evaluated the immune effect of amyloglucosidase extracts of $S$. japonicus (AESJ). After assessing several solvent and enzymatic extracts of $S$. japonicus for their cytotoxicity on murine splenocytes, we selected polysaccharides containing AESJ to study their immunological response on the basis of Th1/Th2 cytokine profiles. Specifically, we assessed the AESJ's effect on Th1 (IFN- $\gamma$, IL-2) and Th2 (IL-4, IL-10) cell phenotypes based on their cytokine profiles with and without it while stimulating murine splenocytes with a well-known $\mathrm{T}$ cell mitogen, Con A.

\section{Materials and Methods}

\section{Experimental animals}

C57BL/6 mice (7-8 weeks) of 20-25 g were housed with NIH07 approved diet and water ad libitum in conventional animal facilities under standard constant temperature $\left(23 \pm 3^{\circ} \mathrm{C}\right)$ and humidity $(50 \pm 5 \%)$. We performed animal experiment in accordance with the guidelines for the Care and Use of Laboratory Animals of the Institutional Ethical Committee of Jeju National University (accreditation No. 2018-0021).

\section{Preparation of splenocyte suspension}

Spleens of the mice were removed and passed through a cell strainer $(40 \mu \mathrm{m})$. Cells were treated with ammonium chloride for $10 \mathrm{~min}$ at room temperature to lyse the red blood cells. Then splenocytes were centrifuged at $221 \times \mathrm{g}$ for $5 \mathrm{~min}$ at room temperature. Separated supernatants were washed with Dulbecco's phosphate buffered saline (DPBS), and spleens were suspended in an RPMI-1640 medium of 10\% fetal bovine serum and 1\% antibiotics. Viable splenocytes were determined by using trypan blue dye, and splenocytes with viability $>90 \%$ were used in further experiments.

\section{Preparation of AMG enzymatic extract from red sea cucumber}

Freeze-dried red sea cucumber was homogenized with a grinder to obtain a fine powder. The enzymatic hydrolytic reaction was performed by using the method described by Ko et al. (2012). Briefly, the powdered $5 \mathrm{~g}$ of S. japonicus was homogenized in $250 \mathrm{~mL}$ of distilled water mixed with AMG, celluclast, viscozyme, alcalase, pepsin, protamax and trypsin enzyme in a substrate to enzyme ratio of 100:1 (w/w). The homogenates were adjusted to its optimal temperature and $\mathrm{pH}$ before enzymatic hydrolysis. The enzymatic reaction was performed for 24 $\mathrm{h}$ and then boiled for $10 \mathrm{~min}$ at $100^{\circ} \mathrm{C}$ to inactivate the enzyme reaction. AMG enzymatic hydrolysates were centrifuged at $142 \times \mathrm{g}$ for $15 \mathrm{~min}$ to remove residues. The supernatants were filtered with Whatman No. 4 filter papers (GE Healthcare, Buckinghamshire, UK). Then, the supernatants obtained from DW extracts of S. japonicus (DESJ), AMG enzymatic extracts of S. japonicus (AESJ), celluclast enzymatic extracts of $S$. japonicus (CESJ), viscozyme enzymatic extracts of S. japonicus (VESJ), 
alcalase enzymatic extracts of $S$. japonicus (ALESJ), pepsin enzymatic extracts of $S$. japonicus (PESJ), protamax enzymatic extracts of S. japonicus (PrESJ), and trypsin enzymatic extracts of S. japonicus (TESJ) were freeze-dried individually and stored under $-20{ }^{\circ} \mathrm{C}$ until use.

\section{Cytotoxicity assay}

The MTT (3-(4,5-dimethylthiazol-2-yl)-2,5-diphenyltetrazolium bromide) assay was used to determine the viability of splenocytes. Splenocytes $\left(1 \times 10^{5}\right)$ were cultured in different concentrations $(0-1,000 \mu \mathrm{g} / \mathrm{mL})$ of organic solutions of protein digest enzymes (viscozymes, protomax, pepsin, trypsin and alcalase) or carbohydrate degrading enzymes (amyloglucosidase, celluclast) and concanavalin A (Con A; $5 \mu \mathrm{g} / \mathrm{mL}$ ) for 48 $\mathrm{h}$ under $5 \% \mathrm{CO}_{2}$ at $37^{\circ} \mathrm{C}$. Three replicates were examined for each experiment. After $48 \mathrm{~h}, 15 \mu \mathrm{L}$ of MTT ( $5 \mathrm{mg} \mathrm{mL} / \mathrm{mL}$ ) was added to each well and kept for $4 \mathrm{~h}$. Created formazan was dissolved with $100 \mu \mathrm{L}$ of solubilization buffer, and the absorbance was measured by using Enzyme-Linked Immunosorbent Assay (ELISA) plates at 570 and $630 \mathrm{~nm}$.

\section{Cell proliferation assay}

To determine the effect of DESJ and AESJ on the proliferation of splenocytes, we performed the ${ }_{3} \mathrm{H}$-thymidine incorporation assay. Splenocytes were cultured in 96-well plates with a density $4 \times 10^{5}$ cells/well, and varying concentrations (0, 3.9, 7.8, $15.6,31.3,62.5,125,250,500,1,000 \mu \mathrm{g} / \mathrm{mL})$ of DESJ or AESJ were applied alone or with Con A $(5 \mu \mathrm{g} / \mathrm{mL})$ stimulation. Three replicates were performed for each experiment. Splenocytes were incubated at $37^{\circ} \mathrm{C}$ with $5 \%$ of $\mathrm{CO}_{2}$ for $54 \mathrm{~h}$. Then, $1 \mu \mathrm{Ci}$ of ${ }^{3} \mathrm{H}$-thymidine (42 $\mathrm{Ci} / \mathrm{mmol}$ specific activity) was added to each well, and plates were incubated for $18 \mathrm{~h}$. Glass fiber filter was used to harvest cells, and the amount of thymidine incorporated into cultured cells was determined by using a liquid scintillation spectrometer (Wallac Micro Beta ${ }^{\circledast}$ TriLux, Perkin Elmer, Waltham, MA, USA).

\section{Measurement of cytokines by enzyme-linked immunosor- bent assay (ELISA)}

Commercially available ELISA kits (Biolegend, San Diego, CA, USA) were used to determine the effect of AESJ on the secretion of cytokines IL-2, IL- $1 \beta$, IFN- $\gamma$, IL- 4 , and IL-10 in splenocytes. Splenocytes were cultured in 24 -well plates $\left(4 \times 10^{6}\right.$ cells/well) and treated with AESJ $(0,31.3,62.5 \mu \mathrm{g} / \mathrm{mL})$ in the presence or absence of Con $\mathrm{A}$ for $48 \mathrm{~h}$ at $37^{\circ} \mathrm{C}$ with $5 \% \mathrm{CO}_{2}$.
Released cytokines in cultured supernatants were measured in a sandwich ELISA using specific capture antibodies according to the manufacturer's instructions.

\section{Data and statistical analysis}

Each experiment was repeated 3 times or more $(n=3+)$ per group. The results of each experiment were expressed as mean \pm SEM. for each group. Student $t$ test was performed using Microsoft Office Excel ${ }^{\circledR} 2013$ program and $p<0.05$ was judged statistically significant.

\section{Results}

\section{Proximate organic and inorganic composition of red sea cu- cumber}

Table 1 shows the approximate organic composition of S. japonicus. High amount of proteins (59.10 $\pm 1.20 \%)$ was observed along with organic components such as carbohydrate (10.53 $\pm 0.54 \%)$ and ash $(6.53 \pm 0.26 \%)$. Lipid content was rather low $(1.30 \pm 0.07 \%)$. In addition, a large number of inorganic compounds were observed in S. japonicus, but considerable variation has been also detected (Table 2). The red sea cucumber contains a total 46,714 ppm of inorganic components, and high amount of $\mathrm{Mg}$ and $\mathrm{P}$ were observed (10,240 \pm 16.26 and $19,346.3 \pm 24.11 \mathrm{ppm}$, respectively). But small amount of $\mathrm{Hg}$ $(0.015 \pm 0.00 \mathrm{ppm})$ and Mo $(0.3 \pm 0.00 \mathrm{ppm})$ were observed. $\mathrm{Mn}, \mathrm{Sn}, \mathrm{Cd}, \mathrm{Co}, \mathrm{Cr}, \mathrm{Ni}, \mathrm{Pb}$, and $\mathrm{Sb}$ were not detected.

\section{Yield and chemical composition of AMG hydrolysates of red sea cucumber}

AMG hydrolysis was performed under the optimum condition at $60{ }^{\circ} \mathrm{C}$ and $\mathrm{pH} 4.5$ (Table 3). As indicated in Table 4, the yield of AMG hydrolysates from red sea cucumber measured by dry weight was $37.00 \pm 2.29 \%$. The AMG hydrolysates contained high level of protein $(49.96 \pm 0.15 \%)$, relatively low level of polysaccharides $(3.65 \pm 0.26 \%)$, and very low polyphenols $(0.43 \pm 0.00 \%)$.

\section{AESJ and DESJ enhance the viability of splenocytes}

To compare the cytotoxicity of different solvent extracts of $S$.

Table 1. Approximate composition of sea cucumber

\begin{tabular}{lllll}
\hline Carbohydrate (\%) & Protein (\%) & Lipid (\%) & Ash (\%) & Moisture (\%) \\
\hline $10.53 \pm 0.54$ & $59.10 \pm 1.20$ & $1.30 \pm 0.07$ & $6.53 \pm 0.26$ & $22.54 \pm 0.96$ \\
\hline Results are represented as mean \pm SEM based on triplicate determinations.
\end{tabular}


Table 2. Inorganic components of sea cucumber

\begin{tabular}{lll}
\hline Inorganic component & $\mathrm{nm}$ & Detection limit $(\mathrm{ppm})$ \\
\hline $\mathrm{Ca}$ & 317.933 & $9,954 \pm 14.14$ \\
$\mathrm{~K}$ & 766.49 & $7,084 \pm 12.73$ \\
$\mathrm{Mg}$ & 285.213 & $10,240 \pm 16.26$ \\
$\mathrm{Fe}$ & 238.204 & $15.2 \pm 0.35$ \\
$\mathrm{Mn}$ & 257.61 & $\mathrm{ND}$ \\
$\mathrm{Cu}$ & 327.393 & $2.3 \pm 0.14$ \\
$\mathrm{Zn}$ & 206.2 & $42.4 \pm 0.78$ \\
$\mathrm{P}$ & 213.617 & $19,346.3 \pm 24.11$ \\
$\mathrm{As}$ & 188.979 & $23.8 \pm 0.99$ \\
$\mathrm{Se}$ & 196.026 & $4.7 \pm 0.50$ \\
$\mathrm{Sn}$ & 189.927 & $\mathrm{ND}$ \\
$\mathrm{Cd}$ & 228.802 & $\mathrm{ND}$ \\
$\mathrm{Co}$ & 228.616 & $\mathrm{ND}$ \\
$\mathrm{Cr}$ & 267.716 & $\mathrm{ND}$ \\
$\mathrm{Li}$ & 670.784 & $1.2 \pm 0.07$ \\
$\mathrm{Mo}$ & 202.031 & $0.3 \pm 0.00$ \\
$\mathrm{Ni}$ & 231.604 & $\mathrm{ND}$ \\
$\mathrm{Pb}$ & 220.353 & $\mathrm{ND}$ \\
$\mathrm{Sb}$ & 206.836 & $\mathrm{ND}$ \\
$\mathrm{Hg}$ & & $0.015 \pm 0.00$ \\
$\mathrm{Besu}$ & &
\end{tabular}

Results are represented as mean \pm SEM based on triplicate determinations. $\mathrm{ND}$, not detected.

Table 3. Optimum conditions of AMG hydrolysis

\begin{tabular}{llll}
\hline Enzyme & $\mathrm{pH}$ & Temperature $\left({ }^{\circ} \mathrm{C}\right)$ & Digested period $(\mathrm{h})$ \\
\hline AMG & 4.5 & 60 & 24 \\
\hline
\end{tabular}

Amyloglucosidase referred as AMG.

AMG, amyloglucosidase.

Table 4. Yield and approximate composition of AMG hydrolysates from sea cucumber

\begin{tabular}{lllll}
\hline & Yield (\%) & Polysaccharide (\%) & Protein (\%) & Polyphenol (\%) \\
\hline AMG & $37.00 \pm 2.29$ & $3.65 \pm 0.263$ & $49.96 \pm 0.15$ & $0.43 \pm 0.00$ \\
\hline
\end{tabular}

Amyloglucosidase referred as AMG. Results are represented as mean \pm SEM based on triplicate determinations.

AMG, amyloglucosidase.

japonicus, we applied varying concentrations $(0-1,000 \mu \mathrm{g} / \mathrm{mL})$ of diverse solvent extracts on murine splenocytes, and the cell viability was measured (Fig. 1). Murine splenocytes treated with DESJ (Fig. 1A) and AESJ (Fig. 1C) revealed significantly increased viability compared to untreated control. Even low concentrations $(\geq 7.8 \mu \mathrm{g} / \mathrm{mL}$ for DESJ and $\geq 31.3 \mu \mathrm{g} / \mathrm{mL}$ for AESJ, respectively) exhibited significantly increased viability, and DESJ, in particular, showed $100 \%$ viability from rather low concentrations (15.6 and $31.3 \mu \mathrm{g} / \mathrm{mL}$ ). To the contrary, EESJ (Fig. 1B), VESJ (Fig. 1E), and PESJ (Fig. 1G) exhibited significant cytotoxicity on murine splenocytes at higher concentrations compared to untreated control (at 1,000 $\mu \mathrm{g} / \mathrm{mL}$ for EESJ and VES); $\geq 500 \mu \mathrm{g} / \mathrm{mL}$ for PESJ, respectively). No significant difference was observed in splenocytes treated with CESJ (Fig. 1D), ALESJ (Fig. 1F), and TESJ (Fig. 1I). In the meantime, PrESJ exhibited more or less steady cell viability compared to untreated control (Fig. 1H). On the basis of above results, we selected AESJ and DESJ and examined further.

\section{AESJ promotes the proliferation of splenocytes}

The proliferation of splenocytes due to DESJ (Fig. 2A) or AESJ (Fig. 2B) treatment in the absence of Con A was measured by using the ${ }^{3} \mathrm{H}$-thymidine incorporation assay. Although DESJ and AESJ revealed very similar proliferation profiles against varying treatment concentrations, the peak concentration of DESJ profile appeared at $31.3 \mu \mathrm{g} / \mathrm{mL}$ and the profile steadily dropped beyond it while that of AESJ appeared at $62.5 \mu \mathrm{g} / \mathrm{mL}$ and the profile dropped rather abruptly beyond it. However, DESJ (3.9-500 $\mu \mathrm{g} / \mathrm{mL})$ did not change the cell proliferation of murine splenocytes significantly but suppressed it significantly $(p<0.05)$ at $1,000 \mu \mathrm{g} / \mathrm{mL}$ compared to untreated control. To the contrary, AESJ increased the cell proliferation significantly $(p<0.05)$ near peak concentrations $(31.3-125 \mu \mathrm{g} / \mathrm{mL})$ but suppressed it significantly $(p<0.05)$ at $1,000 \mu \mathrm{g} / \mathrm{mL}$. On the basis of these results, we selected 31.3 and $62.5 \mu \mathrm{g} / \mathrm{mL}$ of AESJ for further experiments.

\section{AESJ boosts the IL-2, IL-1 $1 \beta$, IL-4, and IL-10 cytokine secretion}

To assess the secretion of proliferation related cytokines IL-2, IL-1 $\beta$, IFN- $\gamma$, IL-4, and IL-10 on murine splenocytes, cells were treated with AESJ ( 31.3 and $62.5 \mu \mathrm{g} / \mathrm{mL}$ ) and the level of secreted cytokines was measured with ELISA. AESJ dose dependently increased the secretion of IL-2 (Fig. 3A), IL-1 3 (Fig. 3C), IL-4 (Fig. 3D), and IL-10 (Fig. 3E) in murine splenocytes. IL-2 secretion significantly $(p<0.05)$ increased by 1.5 and 1.6 folds by AESJ treatments at 31.3 and $62.5 \mu \mathrm{g} / \mathrm{mL}$, respectively, compare to untreated control. The secretion of IL-1 $\beta$ and IL-10 also significantly increased by 3.4 and 4.5 folds respectively compared to untreated control when treated at $62.5 \mu \mathrm{g} / \mathrm{mL}$. IL-4 secretion increased significantly $(p<0.05)$ at $31.3 \mu \mathrm{g} / \mathrm{mL}$. Contrary to other cytokines examined, IFN- $\gamma$ secretion decreased as the 
A

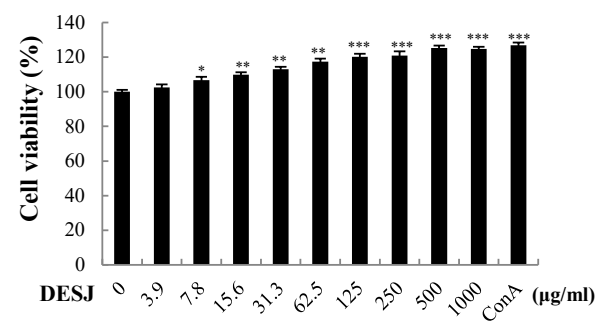

C

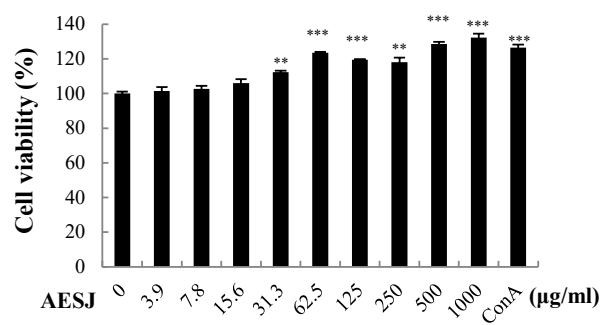

E

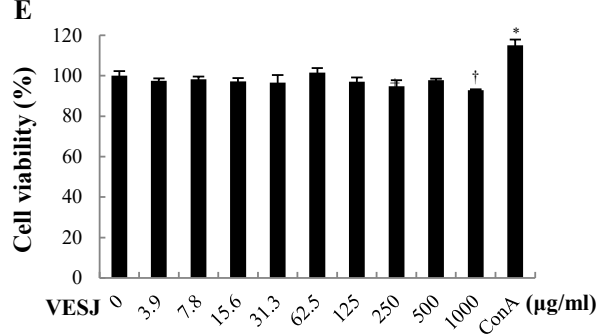

G

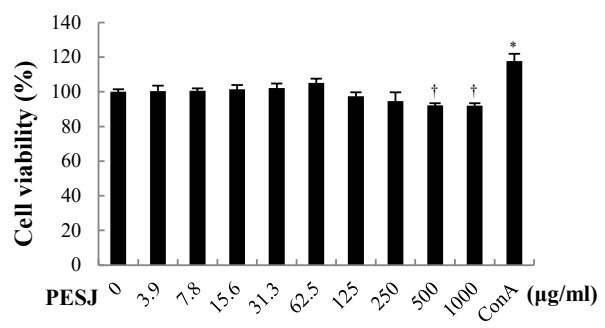

I

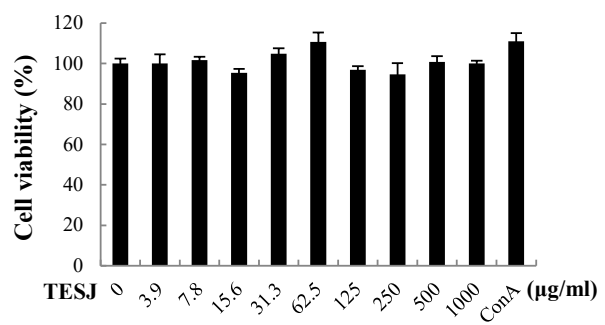

B

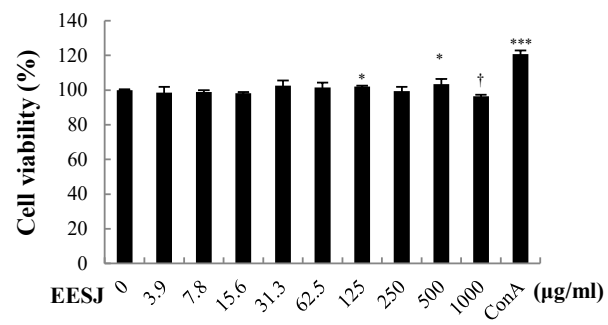

D

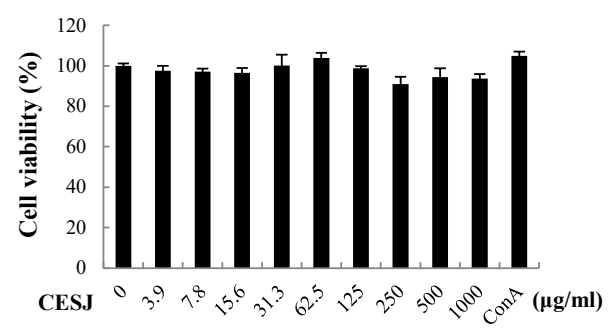

F

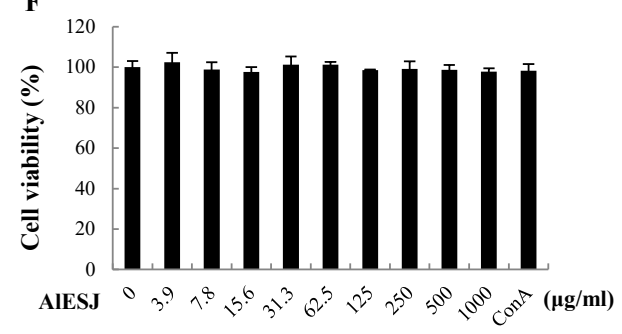

H

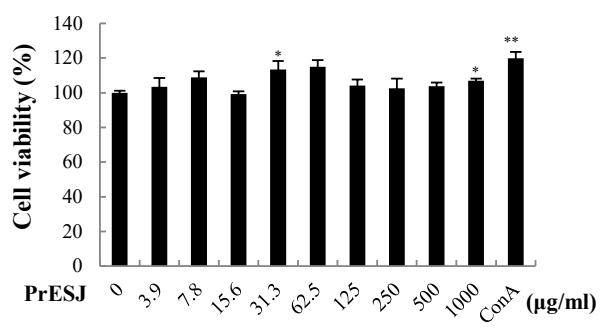

Fig. 1. The effect of different concentrations $(0-1,000 \mu \mathrm{g} / \mathrm{mL})$ of diverse Stichopus japonicus extracts on splenocyte viability after $48 \mathrm{~h}$ incubation. MTT assay was used to measure the viability of splenocytes. (A) DW extracts of S. japonicus (DESJ), (B) 70\% EtOH extracts of S. japonicus (EESJ), (C) AMG enzymatic extracts of S. japonicus (AESJ), (D) celluclast enzymatic extracts of S. japonicus (CESJ), (E) viscozyme enzymatic extracts of S. japonicus (VESJ), (F) alcalase enzymatic extracts of S. japonicus (ALESJ), (G) pepsin enzymatic extracts of S. japonicus (PESJ), (H) protamax enzymatic extracts of S. japonicus (PrESJ), and (I) trypsin enzymatic extracts of S. japonicus (TESJ). Experiments were performed in triplicates, and each bar represents means \pm SEM. ${ }^{*} p<0.05, * * 0.005$, and ${ }^{* * * * *} p<$ 0.0005 represent significant viability increase, and ${ }^{\dagger} p<0.05$ represents significant viability decrease against untreated control group. 
A

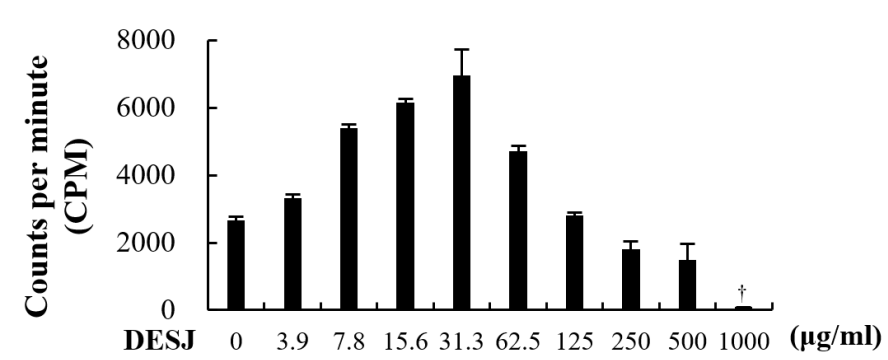

B

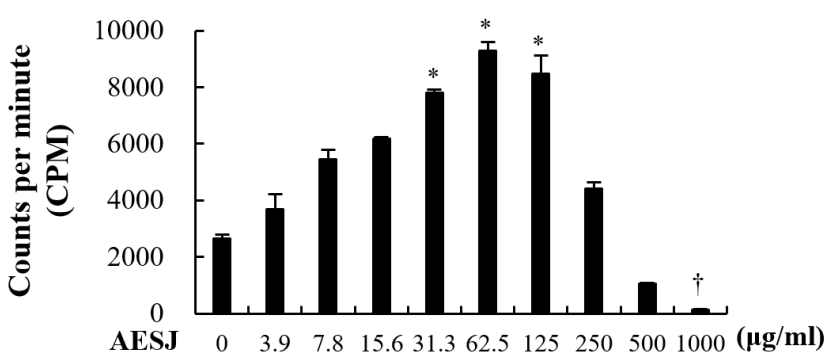

Fig. 2. The effect of (A) DESJ $(0-1,000 \mu \mathrm{g} / \mathrm{mL})$ and AESJ $(0-1,000 \mu \mathrm{g} / \mathrm{mL})$ on the splenocytes proliferation. ${ }^{3} \mathrm{H}$-thymidine incorporation assay was used to measure the proliferation of splenocytes. Proliferation was assessed after the $72 \mathrm{~h}$ of incubation with DESJ and AESJ. Each bar represents a mean \pm SEM. ${ }^{*} p<0.05$ represents statistically significant increase in DESJ or AESJ treated group against untreated control group, and ${ }^{\dagger} p<0.05$ represents statistically significant decrease against untreated control group. DESJ, DW extracts of Stichopus japonicas; AESJ, AMG enzymatic extracts of S. japonicus.

A

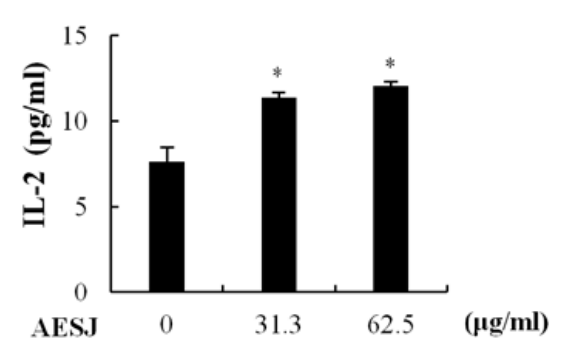

C

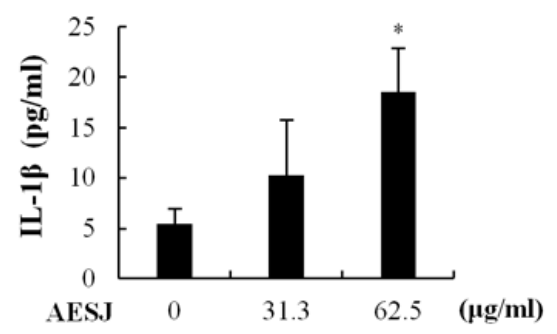

$\mathbf{B}$

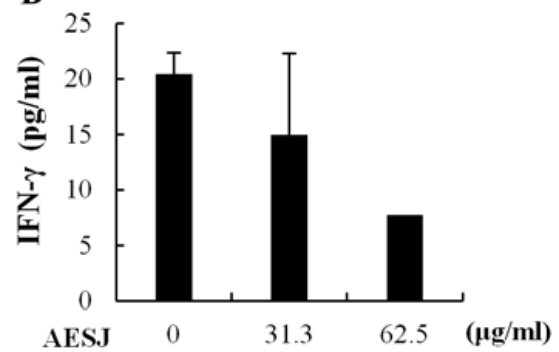

D

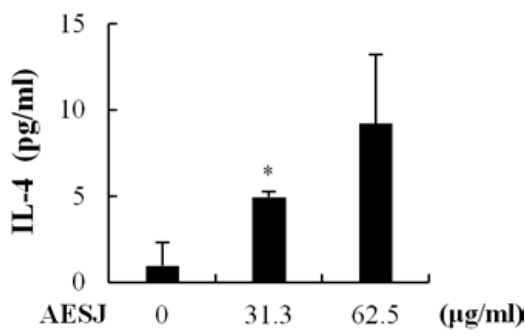

E

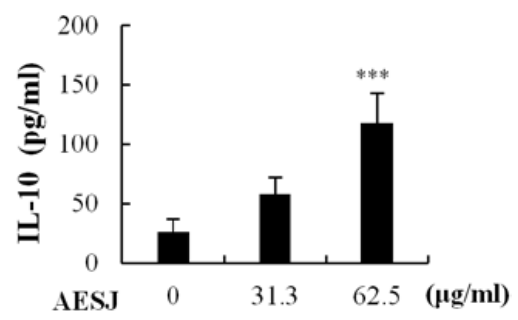

Fig. 3. The effect of AESJ on the level of cytokines (IL-2, IL-1 $\boldsymbol{\beta}$, IFN- $\boldsymbol{\gamma}$, IL-4, and IL-10) in splenocytes. Splenocytes were treated with varying concentrations of AESJ $(31.3,62.5 \mu \mathrm{g} / \mathrm{mL})$ and incubated for $48 \mathrm{~h}$. Cytokine levels were measured by using an ELISA kit. Data are expressed as means \pm SEMs. ${ }^{*} p<0.05$ and ${ }^{* * *} p<0.0005$ represent statistically significant over-expression in AESJ treated groups against untreated control group. ELISA, enzyme-linked immunosorbent assay; AESJ, AMG enzymatic extracts of Stichopus japonicus. 
treatment concentrations were increased (Fig. 3B) though the difference compared to untreated control group was not significant enough.

\section{AESJ inhibits the proliferation of Con A-stimulated murine splenocytes}

To determine the proliferation modulation ability of AESJ, Con A stimulated splenocytes were treated with different concentrations of AESJ and splenocytes' proliferation level was compared with that with Con A only (Fig. 4). When Con A stimulation was applied without any AESJ treatment, splenocytes' proliferation level significantly ( $\mathrm{p}<0.0005)$ increased substantially compared to untreated control, and the increased proliferation level was retained even with low level AESJ treatments $(\leq 31.3 \mu \mathrm{g} / \mathrm{mL})$. However, stimulated spleen cells showed dose dependent decrease in proliferation when treated with concentration $\geq 62.5 \mu \mathrm{g} / \mathrm{mL}$ compared to that of Con A treatment alone by 2.1, 5.2, 8.8, and 11.6 folds respectively with $125,250,500$, and $1,000 \mu \mathrm{g} / \mathrm{mL}$ of AESJ.

\section{AESJ decreases the secretion of IL-2, IL-4 and IL-10 cytokines in Con A-stimulated murine splenocytes}

Con A, a mitogen, stimulates T cells to secrete cytokines. Since AESJ treatment abrogated the effects of Con A stimulation in murine splenocytes, we examined the AESJ's influence on Con A induced cytokine secretion. AESJ significantly $(p<0.0005)$

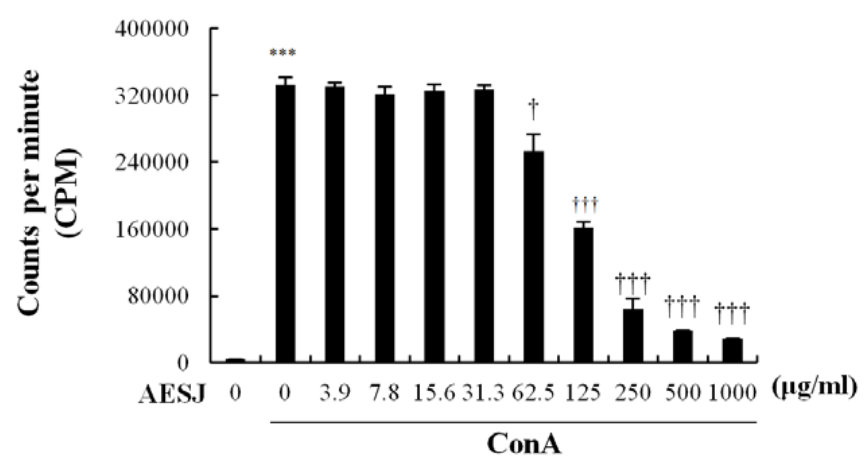

Fig. 4. The effect of different concentrations of AESJ $(0-1,000$ $\mu \mathrm{g} / \mathrm{mL}$ ) on the proliferation of Con A (5 $\mu \mathrm{g} / \mathrm{mL})$ stimulated splenocytes. ${ }^{3} \mathrm{H}$-thymidine incorporation assay was used to measure the proliferation of splenocytes. Data are expressed as means \pm SEMs ${ }^{* * *} p<0.0005$ represent statistically significant increase against untreated control group while ${ }^{\dagger} p<0.05$ and ${ }^{+t+} p<0.0005$ represent statistically significant decrease in Con A stimulated AESJ treated groups against only Con A stimulated control group. AESJ, AMG enzymatic extracts of Stichopus japonicus. suppressed the IL- 2 secretion by 1.7 folds at $62.5 \mu \mathrm{g} / \mathrm{mL}$ respectively compared to Con A alone (Fig. 5A). Moreover, AESJ also dose dependently suppressed the secretion of IL-4 (by 2.5 and 3.8 folds at 31.3 and $62.5 \mu \mathrm{g} / \mathrm{mL}$, respectively; Fig. 5D) and IL-10 (by 1.1 and 1.7 folds at 31.3 and $62.5 \mu \mathrm{g} / \mathrm{mL}$, respectively; Fig. $5 \mathrm{E})$ on Con A stimulated splenocytes. In contrast, we observed dose dependent increase in the secretion of IL-1 $\beta$ (by 3.0 and 3.6 folds at 31.3 and $62.5 \mu \mathrm{g} / \mathrm{mL}$, respectively; Fig. 5C) compared to Con A alone. Interestingly, however, the abrupt production increase of IFN- $\gamma$ group compared to untreated control due to Con A stimulation (14.2 folds) remained unchanged with AESJ treatments (Fig. 5B).

\section{Discussion}

S. japonicus, a marine invertebrate, has gained popularity among researchers in recent decades due to its potential health benefits and therapeutic uses (Bordbar et al., 2011). Its health functions can be attributed to the presence of appreciable amounts of bioactive compounds, especially the triterpene glycosides (saponins), chondroitin sulfates, glycosaminoglycan, sulfated polysaccharides, sterols (glycosides and sulfates), phenolics, peptides, and cerberosides (Bordbar et al., 2011). Diverse sea cucumber species are shown to be effective inductors of cellular immunity. In the present study, we explored the effect of AESJ on splenic cell proliferation and the cytokine profile in Con A stimulated murine splenocytes.

In current study, we used AESJ since this extract has been demonstrated to perform biological activities including immunomodulation (Gómez-Gil et al., 2019). It has also been shown to regulate the immune system through indirect and direct mechanisms including signaling, stimulation and modulation of both cytokines and immune cells (Gómez-Gil et al., 2019). Furthermore, the spleen has been known to play a major role in immunity. It contains a diverse repertoire of immune cells such as macrophages, dendritic cells, $\mathrm{T}$ and $\mathrm{B}$ lymphocytes and more importantly, both innate and adaptive immune processes appear in it, rendering immune reactions in splenocytes a reliable surrogate of the immune responses in the host in general (Wluka \& Olszewski, 2006). A recent study also found that Porphyra yezoensis enzymatic extract increases the proliferation of murine splenocytes (Herath et al., 2018).

Basically the investigation has turned into focused for AMG hydrolysis rather than protease hydrolysis majority due to the point that body wall of sea cucumber mainly consist of 
A

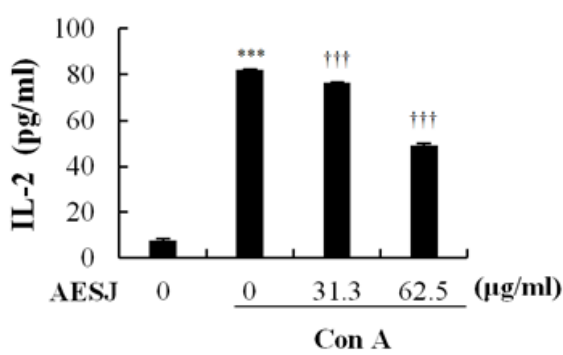

$\mathrm{C}$

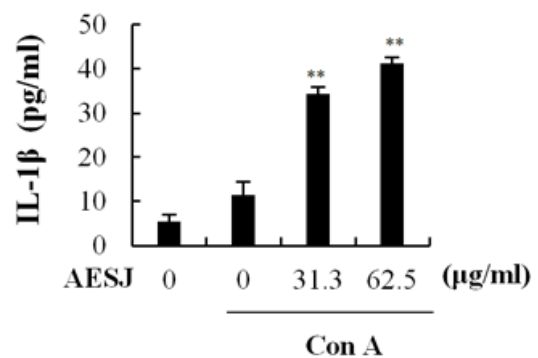

$\mathbf{E}$

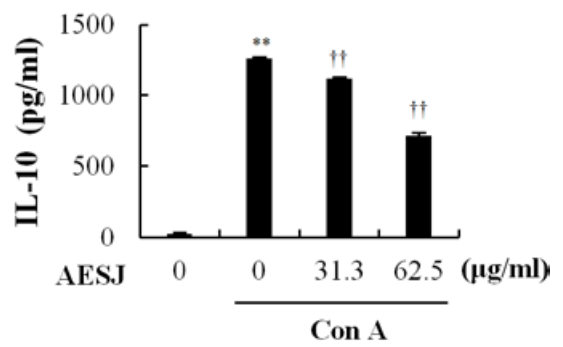

B

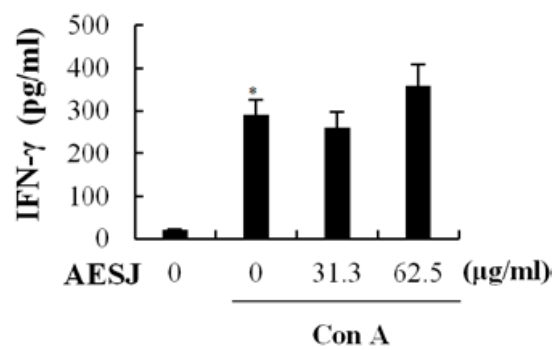

D

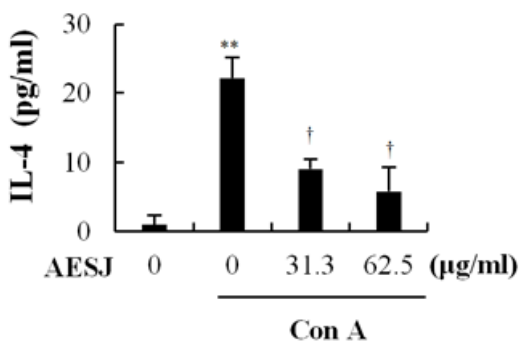

Fig. 5. The effect of AESJ $(31.3,62.5 \mu \mathrm{g} / \mathrm{mL})$ on the production of cytokines (A) IL-2, (B) IFN- $\gamma$, (C) IL-1B, (D) IL-4, and (E) IL-10 in Con A treated splenocytes. Con A stimulated and AESJ treated splenocytes were kept for $48 \mathrm{~h}$ for incubation, and the levels of cytokines were measured by using commercially available ELISA kits. Data are representative of 3 independent experiments, and each bar represents a mean \pm SEM. ${ }^{*} p<0.05,{ }^{* *} p<0.005,{ }^{* * * *} p<0.0005$ represent statistically significant increase in AESJ treated groups against untreated control group, and ${ }^{\dagger} p<0.05,{ }^{+\dagger} p<0.005,{ }^{++t} p<0.0005$ represent statistically significant decrease in Con A stimulated AESJ treated groups against only Con A stimulated control group. ELISA, enzyme-linked immunosorbent assay. AESJ, AMG enzymatic extracts of Stichopus japonicus.

mucopolysaccharides (Duan et al., 2010) and at the same time previous studies proved that the mucopolysacharides has huge impact on immunomodulatory functions (Song et al., 2013). Since AMG has been best known as a breakdown of carbohydrate enzyme, our focused was heavily targeted on AMG than other protease enzymes.

Also it is interesting to note that the selected AMG hydrolysis known to be performed as an economically significant enzyme since its' effectiveness and greater ability of gaining starch and oligosaccharides into $\beta$-d-glucose as a hydrolyzing result (Adeoyo et al., 2018). Moreover, by proving the fact that AMG reveal high content of polysaccharides (Adeoyo et al., 2018) it is obvious to assume that polysaccharides in AMG is responsible for the immunomodulatory function as literature have mentioned the scope of polysaccharides' ability of immunomodulation compared to other components (Zhou et al., 2018). In addition to cell viability data obtain from the present study, the above mentioned aspects made a sense for choosing AMG hydrolysis as the target for further investigations of the current study.

We first disclosed that AESJ was not toxic on murine spleno- 
cytes but rather enhanced their proliferation when applied alone. Specifically, when we evaluated AESJ for its ability to enhance the proliferation of isolated splenocytes, we observed AESJ elicited significant splenocyte proliferative effect in a fair range of concentration (at $31.3-125 \mu \mathrm{g} / \mathrm{mL}$ ), indicating that the extract had a mitogenic effect on lymphocytes. Splenocyte proliferation is vital to both cellular and humoral immune responses due to its considerable sensitivity to diverse lymphocyte proliferation (Benlhassan-Chahour et al., 2003; Cho et al., 2017), and our result provides a rationale for the traditional use of $S$. japonicus as an immunostimulant. A previous study reported that mucopolysacharides of S. japonicus enhanced the $\mathrm{CD}^{3+}$ and $\mathrm{CD}^{4+} \mathrm{T}$ lymphocyte populations in hepatocellular carcinoma induced rats (Song et al., 2013). Moreover, another study also reported that sulphated polysacharides isolated from S. japonicus exhibited potent stimulator activity in RAW264.7 cells (Cao et al., 2017). Viscozyme and AMG had higher polysaccharide content than other digests, which also confirms that enzymatic extraction possesses an innovative advantage over conventional extraction procedures (Affan et al., 2009). These findings signify further evaluation of AESJ's effect on cellular cytokine profile changes.

We revealed that treatments with two different dosages of AESJ $(31.3,62.5 \mu \mathrm{g} / \mathrm{mL})$ enhanced the secretion of IL-2 (Th1), and IL-1 $\beta$, IL-4, IL-10 (Th2) cytokines when treated alone. Cytokines perform a pivotal role in immune system, mediating cell-cell communication and improving host defense mechanism (Lacy \& Stow, 2011). Th1 cells which produce IFN- $\gamma$, IL2 , and TNF- $\alpha$ are known important in cell mediated immunity and phagocytic activity (Romagnani, 2000). IL-2 is a pivotal inducer of suppressive T cells. It works as a key growth and death factor of pathogen activated T lymphocytes, and IL-2 deficient mice exhibit autoimmune diseases (Malek, 2003). In the meantime, Th2 cytokines further induce the secretion of the Th1 cytokine IFN- $\gamma$ which is primarily secreted by activated $\mathrm{T}$ cells and natural killer cells (Puddu et al., 2005). AESJ's potential to enhance the production of IL-2 (Th1) might also be therapeutically involved in eliminating cancerous cells and pathogens including viruses (Kidd, 2003).

Similarly, Th2 cells which produce IL- 4 and IL-10 perform a critical role in humoral immunity and antibody production, and play a dominant role in allergic and stress responses (Romagnani, 2000). When applied alone, AESJ dose dependently enhanced the secretion of IL- 4 that induces the differentiation of Th cells into Th2 cells and the growth of B cells while being a crucial participant in allergic inflammation. Also, AESJ boosted the secretion of IL-10 that performs important functions such as phagocytosis, release of immune mediators, and antigen presentation when applied alone (Chung et al., 2007). Protein-sulfated fucans, a polysaccharide in AESJ, might be responsible for the enhanced secretion of IL-10 in splenocytes (Cao et al., 2017). AESJ's potential to enhance the production of IL-4 and IL-10 (Th2) might be therapeutically beneficial against diseases such as rheumatoid arthritis (Steen-Louws et al., 2019).

In this study, we initiated immune responses in splenocytes using Con $\mathrm{A}$, an antigen known to enhance the proliferation of T-lymphocytes in murine splenocytes (Lei \& Chang, 2009). Con A stimulation activates macrophages and neutrophils as well (Cameron et al., 1983). When mice are treated with Con A, it can increase the secretion of inflammatory cytokines like IL-2, IL-4, IL-6, IL-10, IL-12, TNF- $\alpha$, and IFN- $\gamma$ (Sass et al., 2002). However, over-activation of immune system can drive the progression of inflammatory and autoimmune diseases, and immune suppressants can be beneficial to maintain immune balance (Herath et al., 2019). Of note, cytokines have been known to play a key role in pathogenesis of autoimmune diseases. More importantly, pro-inflammatory cytokines are found responsible for initiation of autoimmune inflammation while anti-inflammatory cytokines are found responsible for regression and prevention of acute phase of diseases (Moudgil \& Choubey, 2011). The IFN- $\gamma$ is one of key Th1 cytokines which stimulate recruitment of macrophages and macrophages in-turn secrete pro-inflammatory cytokines like IL-1 $\beta$ and are responsible for development of lymphocytes (Herath et al., 2019). At the same time IL-4, one of major Th2 cytokines, demonstrated in autoimmune diseases which activate macrophage and equipping macrophage (Yang et al., 2017).

The polysaccharide extract has ability to enhance the expression of different cytokine profile that might increase immune responses and lymphocyte proliferation (Doskocil et al., 2016). The investigation of effectiveness of immune cell population may accounts for immunomodulatory mechanism induce by an external agent as various $\mathrm{CD}^{4+}$ subpopulations gain much attention (Da Silva et al., 2014). However, naïve $\mathrm{CD}^{4+} \mathrm{T}$ cells may lead the differentiation of few linage of Th cells including Th1, Th2, and Th17 or else regulatory T cells. Th1 cells responsible for the secretion of IFN- $\gamma$ and IL-2 (Zhu \& Paul, 2010).

Furthermore, it has been noted that polysaccharides rich extracts able to enhance the Con A induced spleen IL-2 and IFN- $\gamma$ in C57BL/6 mice (Yan et al., 2013) assuming the literature hypotheses that extract might stimulated spleen cells also 
induced cell activation and proliferation. It is important to mention that proliferation of splenocytes responsible for activation cascade of both cellular and humoral immune responses while splenic natural killer mediate for the potential of immunomodulation (Han et al., 2019). Literature have been investigated the fact of "fucan" in polysaccharides significantly induced mRNA expression of cytokines generation including IL-10 that might potentially cure the diseases via immunomodulatory activity (Oh et al., 2017). Although the mechanism is still remain to be investigated, the literature it can be assumed that $S$. japonicus has potential to treatment and prevention of human diseases including cancer and allergic disorders through immunomodulatory activity (Oh et al., 2017).

In our study, we found that, while Con A significantly enhanced the proliferation of murine splenocytes, AESJ (> 62.5 $\mu \mathrm{g} / \mathrm{mL}$ ) attenuated the cell proliferation of Con A stimulated splenocytes when applied together. A previous report identified that mucopolysaccharides in S. japonicus could incur the immunomodulatory activity via recovering the population of $\mathrm{CD}^{3+}$ and $\mathrm{CD}^{4+} \mathrm{T}$ cells in rats induced of hepatocellular carcinoma (Khotimchenko, 2018). Therefore, we assume that polysaccharides in AESJ might be responsible for the observed down regulated secretion of Th1 (IL-2) and Th2 (IL-4, IL-10) cytokines in Con A stimulated splenocytes. Interestingly, however, the secretion of IFN $\gamma$ was not affected by AESJ regardless of whether splenocytes were stimulated with Con A or not.

These results suggest that AESJ boosted the splenocyte proliferation and the production of cytokines, IL-2 (Th1) and IL-4, IL-10 (Th2), when treated alone. However, when treated to Con A stimulated splenocytes, AESJ reversed the Con A's activation of splenocytes: it decreased the proliferation of splenocytes and the secretion of cytokines from Con A stimulated immune cells. Observed immunomodulatory effect of AESJ might be related to the function of polysaccharides of $S$. japonicus, the main compound of its body wall. Therefore, AESJ may be further developed as a natural candidate of maintaining the homeostasis of immune system.

\section{Competing interests}

No potential conflict of interest relevant to this article was reported.

\section{Funding sources}

This research was a part of the project titled 'JEJU SEA GRANT', funded by the Ministry of Oceans and Fisheries, Korea (Project
No. 20180030).

\section{Acknowledgements}

The authors wish to thank Dr. T.H. Chung for the editorial assistance.

\section{Availability of data and materials}

The datasets supporting the conclusions of this article are included within the article.

\section{Ethics approval and consent to participate}

We performed animal experiment in accordance with the guidelines for the Care and Use of Laboratory Animals of the Institutional Ethical Committee of Jeju National University (accreditation No. 2018-0021).

\section{ORCID}

Suyama Prasansali Mihindukulasooriya https://orcid.org/0000-0003-0568-4002

Bohyung Kim https://orcid.org/0000-0003-3355-5216 Duong Thi Thuy Dinh https://orcid.org/0000-0001-9664-1264 Kalahe Hewage Iresha Nadeeka Madushani Herath https://orcid.org/0000-0002-8607-2659

Jinhee Cho

Hyo Jin Kim https://orcid.org/0000-0002-4402-8174

Youngheun Jee https://orcid.org/0000-0003-4342-4711 https://orcid.org/0000-0002-6295-0314

\section{References}

Abood WN, Fahmi I, Abdulla MA, Ismail S. Immunomodulatory effect of an isolated fraction from Tinospora crispa on intracellular expression of INF- $\gamma$, IL-6 and IL-8. BMC Complement Altern Med. 2014;14:205.

Adeoyo OR, Pletschke BI, Dames JF. Purification and characterization of an amyloglucosidase from an ericoid mycorrhizal fungus (Leohumicola incrustata). AMB Express. 2018;8:154.

Affan A, Heo SJ, Jeon YJ, Lee JB. Optimal growth conditions and antioxidative activities of Cylindrotheca closterium (Bacillariophyceae). J Phycol. 2009;45:1405-15.

Azam S, Jakaria M, Kim IS, Kim J, Haque ME, Choi DK. Regulation of toll-like receptor (TLR) signaling pathway by polyphenols in the treatment of age-linked neurodegenerative diseases: focus on TLR4 signaling. Front Immunol. 2019;10:1000

Benlhassan-Chahour K, Penit C, Dioszeghy V, Vasseur F, Janvi- 
er G, Rivière Y, et al. Kinetics of lymphocyte proliferation during primary immune response in macaques infected with pathogenic simian immunodeficiency virus SIVmac251: preliminary report of the effect of early antiviral therapy. J Virol. 2003;77:12479-93.

Bordbar S, Anwar F, Saari N. High-value components and bioactives from sea cucumbers for functional foods: a review. Mar Drugs. 2011;9:1761-805.

Cameron AR, Nelson J, Forman HJ. Depolarization and increased conductance precede superoxide release by concanavalin A-stimulated rat alveolar macrophages. Proc Natl Acad Sci USA. 1983;80:3726-8.

Cao RA, Surayot U, You S. Structural characterization of immunostimulating protein-sulfated fucan complex extracted from the body wall of a sea cucumber, Stichopus japonicus. Int J Biol Macromol. 2017;99:539-48.

Cho J, Bing SJ, Kim A, Lee NH, Byeon SH, Kim GO, et al. Beetroot (Beta vulgaris) rescues mice from $\gamma$-ray irradiation by accelerating hematopoiesis and curtailing immunosuppression. Pharm Biol. 2017;55:306-16.

Chung EY, Liu J, Homma Y, Zhang Y, Brendolan A, Saggese $\mathrm{M}$, et al. Interleukin-10 expression in macrophages during phagocytosis of apoptotic cells is mediated by homeodomain proteins $\mathrm{Pbx} 1$ and Prep-1. Immunity. 2007;27:P952-64.

Da Silva TA, de Souza MA, Cecílio NT, Roque-Barreira MC. Activation of spleen cells by ArtinM may account for its immunomodulatory properties. Cell Tissue Res. 2014;357:719-30.

Doskocil I, Havlik J, Verlotta R, Tauchen J, Vesela L, Macakova $\mathrm{K}$, et al. In vitro immunomodulatory activity, cytotoxicity and chemistry of some central European polypores. Pharm Biol. 2016;54:2369-76.

Duan X, Zhang M, Mujumdar AS, Wang S. Microwave freeze drying of sea cucumber (Stichopus japonicus). J Food Eng. 2010;96:491-7.

Gómez-Gil E, Franco A, Madrid M, Vázquez-Marín B, Gacto M, Fernández-Breis J, et al. Quorum sensing and stress-activated MAPK signaling repress yeast to hypha transition in the fission yeast Schizosaccharomyces japonicus. PLOS Genet. 2019;15:e1008192.

Han L, Meng M, Guo M, Cheng D, Shi L, Wang X, et al. Immunomodulatory activity of a water-soluble polysaccharide obtained from highland barley on immunosuppressive mice models. Food Funct. 2019;10:304-14.
Heo SJ, Park EJ, Lee KW, Jeon YJ. Antioxidant activities of enzymatic extracts from brown seaweeds. Bioresour Technol. 2005;96:1613-23.

Herath KHINM, Cho J, Kim A, Kim HS, Han EJ, Kim HJ, et al. Differential modulation of immune response and cytokine profiles of Sargassum horneri ethanol extract in murine spleen with or without Concanavalin A stimulation. Biomed Pharmacother. 2019;110:930-42.

Herath KM, Lee JH, Cho J, Kim A, Shin SM, Kim B, et al. Immunostimulatory effect of pepsin enzymatic extract from Porphyra yezoensis on murine splenocytes. J Sci Food Agric. 2018;98:3400-8.

Himaya SWA, Ryu B, Qian ZJ, Kim SK. Sea cucumber, Stichopus japonicus ethyl acetate fraction modulates the lipopolysaccharide induced iNOS and COX-2 via MAPK signaling pathway in murine macrophages. Environ Toxicol Pharmacol. 2010;30:68-75.

Khotimchenko Y. Pharmacological potential of sea cucumbers. Int J Mol Sci. 2018;19:1342.

Kidd P. Th1/Th2 balance: the hypothesis, its limitations, and implications for health and disease. Altern Med Rev. 2003;8:223-46.

Ko SC, Lee JK, Byun HG, Lee SC, Jeon YJ. Purification and characterization of angiotensin I-converting enzyme inhibitory peptide from enzymatic hydrolysates of Styela clava flesh tissue. Process Biochem. 2012;47:34-40.

Lacy P, Stow JL. Cytokine release from innate immune cells: association with diverse membrane trafficking pathways. Blood. 2011;118:9-18.

Lei HY, Chang CP. Lectin of Concanavalin A as an anti-hepatoma therapeutic agent. J Biomed Sci. 2009;16:10.

Malek TR. The main function of IL-2 is to promote the development of T regulatory cells. J Leukoc Biol. 2003;74:961-5.

Moudgil KD, Choubey D. Cytokines in autoimmunity: role in induction, regulation, and treatment. J Interferon Cytokine Res. 2011;31:695-703.

Oh GW, Ko SC, Lee DH, Heo SJ, Jung WK. Biological activities and biomedical potential of sea cucumber (Stichopus japonicus): a review. Fish Aquatic Sci. 2017;20:28.

Ortuño-Sahagún D, Zänker K, Rawat AKS, Kaveri SV, Hegde P. Natural immunomodulators. J Immunol Res. 2017;2017:7529408.

Puddu P, Carollo M, Pietraforte I, Spadaro F, Tombesi M, Ramoni C, et al. IL-2 induces expression and secretion of IFN- $\gamma$ in murine peritoneal macrophages. J Leukoc Biol. 
2005;78:686-95.

Romagnani S. T-cell subsets (Th1 versus Th2). Ann Allergy Asthma Immunol. 2000;85:9-18.

Sass G, Heinlein S, Agli A, Bang R, Schümann J, Tiegs G. Cytokine expression in three mouse models of experimental hepatitis. Cytokine. 2002;19:115-20.

Song Y, Jin SJ, Cui LH, Ji XJ, Yang FG. Immunomodulatory effect of Stichopus japonicus acid mucopolysaccharide on experimental hepatocellular carcinoma in rats. Molecules. 2013;18:7179-93.

Steen-Louws C, Hartgring SAY, Popov-Celeketic J, Lopes AP, de Smet MBM, Eijkelkamp N, et al. IL4-10 fusion protein: a novel immunoregulatory drug combining activities of interleukin 4 and interleukin 10. Clin Exp Immunol. 2019;195:1-9.

Taiyeb-Ali TB, Zainuddin SLA, Swaminathan D, Yaacob H. Efficacy of 'Gamadent' toothpaste on the healing of gingival tissues: a preliminary report. J Oral Sci. 2003;45:153-9.

Wargasetia TL, Widodo. Mechanisms of cancer cell killing by sea cucumber-derived compounds. Invest New Drugs. 2017;35:820-6.

Wijesinghe WAJP, Jeon YJ. Enzyme-assistant extraction (EAE) of bioactive components: a useful approach for recovery of industrially important metabolites from seaweeds: a review. Fitoterapia. 2012;83:6-12.

Wluka A, Olszewski WL. Innate and adaptive processes in the spleen. Ann Transplant. 2006;11:22-9.

Yan J, Ma Y, Zhao F, Gu W, Jiao Y. Identification of immunomodulatory signatures induced by American ginseng in murine immune cells. Evid Based Complement Alternat Med. 2013;2013:972814.

Yang WC, Hwang YS, Chen YY, Liu CL, Shen CN, Hong WH, et al. Interleukin-4 supports the suppressive immune responses elicited by regulatory T cells. Front Immunol. 2017;8:1508.

Ye J, Shen C, Huang Y, Zhang X, Xiao M. Anti-fatigue activity of sea cucumber peptides prepared from Stichopus japonicus in an endurance swimming rat model. J Sci Food Agric. 2017;97:4548-56.

Zhou X, Dong Q, Kan X, Peng L, Xu X, Fang Y, et al. Immunomodulatory activity of a novel polysaccharide from Lonicera japonica in immunosuppressed mice induced by cyclophosphamide. PLOS ONE. 2018;13:e0204152.

Zhu J, Paul WE. Heterogeneity and plasticity of T helper cells. Cell Res. 2010;20:4-12. 